\title{
Akibat Hukum Pengusaha Melakukan Perbuatan Curang pada Masa Pandemi Dikaitkan dengan Perundang-Undangan Yang Berlaku
}

\author{
Abraham Radja ${ }^{1}$, Imam Haryanto ${ }^{2}$ \\ Fakultas Hukum Universitas Pembangunan Nasional Veteran Jakarta \\ J1. Rs. Fatmawati Raya, Pd. Labu, Kec. Cilandak, Kota Depok, Jawa Barat 12450 \\ Correspondence email: abrahamradja20@gmail.com, Imam.upns1@gmail.com
}

\begin{abstract}
Abstrak. Penulisan ini dilakukan untuk mengetahui perbuatan curang yang dilakukan pelaku usaha pada masa pandemi dan bagaimana akibat hukum yang timbul dari perbuatan curang tersebut. Penelitian ini secara yuridis normative dengan pendekatan undang-undang dengan menggunakan jenis data bersifat sekunder yang dikumpulkan melalui studi kepustakaan. Dari penulisan ini dapat diambil kesimpulan bahwa posisi dominan, penetapan harga, dan penimbunan merupakan suatu bentuk perbuatan curang yang saling berkaitan yang dilakukan oleh para pelaku usaha dalam masa pandemi yang terjadi sekarang ini. Pemberian sanksi administratif, pidana denda, pidana kurungan pengganti denda ataupun pidana tambahan apabila memenuhi ketentuan yang berlaku bagi para pihak yang melakukan beberapa bentuk kecurangan selama masa pandemic.
\end{abstract}

Kata Kunci: Akibat Hukum, Perbuatan Curang, Pandemi

Abstract. This writing is written to find out the fraudulent acts committed by business actors during the pandemic and how the legal consequences arise from these fraudulent acts. This research is a juridical normative type with a statutory approach using secondary data collected through literature study. From this writing, it can be concluded that dominant position, Price fixing, and hoarding are a form of fraudulent and interrelated acts committed by business actors in the current pandemic era. Administrative sanctions, fines, imprisonment or additional penalties are given to comply with the applicable provisions for parties who commit several forms of fraud during the pandemic period.

Keyword: Legal Consequences, Fraud, Pandemic

\section{PENDAHULUAN}

Pelaku usaha adalah setiap orang perorangan atau badan usaha, baik yang berbentuk badan hukum atau bukan badan hukum yang didirikan dan berkedudukan atau melakukan kegiatan dalam wilayah h ukum negara Republik Indonesia, baik sendiri maupun bersama-sama melalui perjanjian, menyelenggarakan berbagai kegiatan usaha dalam bidang ekonomi. ${ }^{1}$ Dalam setiap kegiatan pelaku usaha ini tentu adanya tindakan-tindakan yang tidak boleh dilakukan contohnya seperti melakukan persaingan usaha secara tidak sehat yang dapat diartikan sebagai kegiatan yang dilakukan antar para pelaku usaha dalam kegiatan usaha produksi maupun kegiatan pemasaran barang atau jasa yang dilakukan secara tidak jujur dan menghambat kegiatan dari masing-masing pelaku usaha. Menurut Undang-Undang No. 5 Tahun 1999 tentang Larangan Praktek Monopoli dan Persaingan Usaha Tidak Sehat, persaingan usaha tidak sehat dapat diartikan sebagai Persaingan usaha tidak sehat adalah "persaingan antarpelaku usaha dalam menjalankan kegiatan produksi dan atau pemasaran barang dan atau jasa yang dilakukan dengan cara tidak jujur atau melawan hukum atau menghambat persaingan usaha." Dalam kegiatan usaha ini harus adanya pihak lain yang dapat membuat kegiatan pelaku usaha menjadi berguna dan mencapai tujuannya, pihak tersebut merupakan pihak konsumen. Konsumen menurut Undang-Undang No. 8 Tahun 1999 tentang perlindungan konsumen adalah setiap orang pemakai barang dan/atau jasa yang tersedia dalam masyarakat, baik bagi kepentingan diri sendiri, keluarga, orang lain, maupun makhluk hidup lain dan tidak untuk diperdagangkan. ${ }^{3}$

Henry Clay (1832) mengungkapkan bahwa: "Off all human powers operating on the affairs of mankind, none is greater than that of competition, (Dari semua kekuatan manusia yang beroperasi pada urusan umat manusia, tidak ada yang lebih besar dari persaingan)" untuk menjelaskan mengenai arti penting dari persaingan untuk umat manusia. Bahkan adanya kemungkinan sejak dimulainya peradaban dan selama masih akan ada peradaban persaingan tidak akan pernah bisa dipisahkan dari kehidupan manusia. ${ }^{4}$ Persaingan merupakan suatu hal yang sangat penting bagi kehidupan manusia tidak terlepas dalam usaha mereka, setiap orang bersaing untuk mencapai apa yang mereka harapkan atau cita-citakan, dikarenakan hal tersebut terkadang seseorang menghalalkan beberapa cara untuk mencapai

\footnotetext{
${ }^{1}$ Undang-Undang No.5 Tahun 1999 Tentang Larangan Praktek Monopoli dan Persaingan Usaha Tidak Sehat Pasal 1 huruf E

${ }^{2}$ Undang-Undang No.5 Tahun 1999 Tentang Larangan Praktek Monopoli dan Persaingan Usaha Tidak Sehat Pasal 1 huruf F

${ }^{3}$ Undang-Undang No.8 Tahun 1999 Tentang Perlindungan Konsumen Pasal 1 ayat 2

${ }^{4}$ Ditha Wiradiputra, S.H. (Staf Pengajar FHUI, Direktur Eksekutif Lembaga Kajian Persaingan dan Kebijakan Usaha FHUI), Modul untuk Retooling Program under Employee Graduates at Priority Disiciplines under TPSDP (Technology and Profesional Skills Development Sector Project) DIKTI., Jakarta. Pengantar Hukum Persaingan Usaha Indonesia. 2004.
} 
hal tersebut, entah dengan melakukan kecurangan maupun memanfaatkan kekuasaan mereka akan suatu barang atau jasa demi melancarkan kegiatan usaha mereka. Oleh karena itu pentingnya suatu hukum yang dapat mengikat dan mengatur kegiatan usaha mereka agar meminimalisir atau menghilangkan kegiatan kecurangan mereka, contohnya Undang-Undang Nomor 5 Tahun 1999 tentang Larangan Praktek Monopoli dan Persaingan Usaha Tidak Sehat dan juga Undang-Undang Nomor 7 Tahun 2014 tentang Perdagangan, kedua undang-undang tersebut sangat berperan dalam lancarnya kegiatan ekonomi. Tetapi dalam setiap kegiatan ekonomi diperlukannya konsumen demi tercapainya suatu kegiatan ekonomi yang baik dan seimbang oleh karena itu pentingnya juga untuk setiap pelaku usaha memahami dan menjalankan Undang-Undang Nomor 8 tentang Perlindungan Konsumen.

Perlindungan terhadap konsumen masih dianggap remeh oleh beberapa oknum maupun kelompok pelaku usaha yang dimana para konsumen tidak mendapatkan hak-hak yang seharusnya mereka dapatkan. Tujuan dari penelitian ini adalah untuk mengetahui hukum yang mengatur dan menegaskan hak dan wewenang yang dimiliki pelaku usaha serta penegakkan akan kegiatan pelaku usaha yang dilarang dalam proses usahanya dan sesuai dengan ketentuan yang berlaku sehingga menciptakan suatu usaha yang sehat. Dalam masa-masa pandemi masih adanya para pelaku usaha yang memanfaatkan kondisi dan kemampuan mereka untuk melakukan kecurangan dalam melakukan proses usahanya beberapa kecurangan yang dilakukan adalah dengan melakukan penimbunan barang, permainan harga, sehingga ketersediaan barang menjadi langka selain itu juga dengan melakukan kenaikan harga secara tidak wajar setiap hal tersebut sangat bertentangan dengan Undang-undang Praktek Monopoli dan perdagangan karena melanggar beberapa ketentuan dalam Undang-undang tersebut, serta berkaitan juga dengan Undang-undang perlindungan konsumen dikarenakan kewajiban sebagai seorang pelaku usaha. Bukan hanya hal tersebut beberapa pelaku usaha juga masih belum memehami tentang kewajiban dan hak yang ia miliki sebegai pelaku usaha sehingga tidak melakukan proses usahanya secara maksimal, bahkan masih adanya pelaku usaha yang tidak mengetahui apa yang dilarang dalam melakukan proses usahanya. setiap kegiatan yang dilakukan dalam perdagangan pasti akan memiliki hubungan dengan Oleh karena itu penulis tertarik untuk membahas mengenai akibat hukum perbuatan curang yang dilakukan oleh para pelaku usaha selama masa pandemi.

\section{METODE}

Jenis yang digunakan dalam peneltian ini adalah metode penelitian hukum dengan jenis yuridis normatif. Pendekatan perundang-undangan, jenis data yang dikumpulkan bersifat sekunder, dengan demikian maka cara pengumpulan data yang digunakan adalah studi kepustakaan sesuai dengan yang terkait masalah yang diteliti yakni tentang akibat hukum pengusaha melakukan perbuatan curang pada masa pandemi.

\section{HASIL DAN PEMBAHASAN}

\section{Perbuatan curang pada masa pandemi dikaitkan dengan perundang-undangan yang berlaku}

Sebelum membahas mengenai perbuatan curang yang dilakukan oleh pengusaha dan pelaku usaha perlu kita ketahui terlebih dahulu mengenai KPPU (Komisi Pengawas Persaingan Usaha). KPPU merupakan suatu lembaga independent yang dibentuk untuk mengawasi jalannya Undang-Undang Nomor 5 Tahun 1999 tentang Larangan Praktik Monopoli dan Persaingan Usaha Tidak Sehat, mereka bertanggung jawab langsung terhadap presiden dalam melaksanakan tugas-tugasnya.

Untuk membahas mengenai perbuatan curang kita perlu mengetahui mengenai apa yang dimaksud dengan hal tersebut. Perbuatan curang merupakan tindakan ketidak jujuran atau dengan kelicikan dilakukan secara sengaja tanpa disadari oleh pihak yang dirugikan untuk mendapatkan manfaat atau keuntungan untuk dirinya sendiri.

Perbuatan curang bukanlah suatu hal yang baru lagi, perbuatan curang ini biasa terjadi pada suatu kegiatan usaha maupun pemerintah untuk mencapai tujuan mereka secara egois untuk mendapatkan keuntungan yang signifikan. Dalam masa pandemi yang terjadinya banyaknya para pelaku usaha atau pengusaha yang melakukan kegiatan usaha mereka secara curang (Polda Sulsel Bongkar Penyalahgunaan Perdagangan 22 Ribu Masker di Makassar) ${ }^{5}$ kegiatannya merupakan menguasai suatu produk sehingga mendapatkan posisi dominan dan Price fixing (penetapan harga) salah satu contoh tersebut.

\section{Posisi dominan}

Posisi dominan menurut KBBI secara harfiah memiliki arti kata "posisi" adalah kedudukan (orang atau barang) sementara arti kata "dominan" adalah bersifat sangat menentukan karena kekuasaan, pengaruh, tampak menonjol. Posisi dominan subsatansinya diatur dalam Pasal 1 Angka 4 Undang-Undang Nomor 5 Tahun 1999 tentang Larangan Praktek Monopoli dan Persaingan Usaha Tidak Sehat menurut pasal tersebut posisi dominan adalah "keadaan dimana pelaku usaha tidak mempunyai pesaing yang berarti di pasar bersangkutan dalam kaitan dengan pangsa pasar yang

https://humas.polri.go.id/download/polda-sulsel-bongkar-penyalahgunaan-perdagangan-22-ribu-masker-di-makassar/ (diakses pada tanggal 5 April 2021 pukul 20.00) 
dikuasai, atau pelaku usaha mempunyai posisi tertinggi diantara pesaingnya di pasar bersangkutan dalam kaitan dengan kemampuan keuangan, kemampuan akses pada pasokan atau penjualan, serta kemampuan untuk menyesuaikan pasokan atau permintaan barang atau jasa tertentu". Poisi dominan juga dapat diartikan "sebagai kemampuan untuk menguasai atau untuk mempertahankan posisi di pasar bersangkutan juga bisa dilakukan melalui kegiatan persaingan usaha yang tidak sehat. Umpamanya, pelaku usaha, baik secara sendiri maupun bersama-sama, menciptakan hambatan persaingan (competition restraint) bagi pesaingnya maupun pesaing potensialnya, seperti menghambat masuknya pesaing potensial, membatasi produksi pesaing, menghambat perkembangan pasar serta teknologi dan berbagai perilaku yang unfair lainnya. Berkurangnya persaingan yang diakibatkan dari tindakan ini bisa berakibat pada konsumen yang dapat merugikan mereka."

\section{Menurut pasal 25 Undang-Undang Nomor 5 Tahun 1999}

“(1) Pelaku usaha dilarang menggunakan posisi dominan baik secara langsung maupun tidak langsung untuk: a. menetapkan syarat-syarat perdagangan dengan tujuan untuk mencegah dan atau menghalangi konsumen memperoleh barang dan atau jasa yang bersaing, baik dari segi harga maupun kualitas; atau b. membatasi pasar dan pengembangan teknologi; atau c. menghambat pelaku usaha lain yang berpotensi menjadi pesaing untuk memasuki pasar bersangkutan. (2) Pelaku usaha memiliki posisi dominan sebagaimana dimaksud ayat (1) apabila: a. satu pelaku usaha atau satu kelompok pelaku usaha menguasai 50\% (lima puluh persen) atau lebih pangsa pasar satu jenis barang atau jasa tertentu; atau b. dua atau tiga pelaku usaha atau kelompok pelaku usaha menguasai 75\% (tujuh puluh lima persen) atau lebih pangsa pasar satu jenis barang atau jasa tertentu."

Perusahaan yang memiliki kekuatan dalam pasar pada suatu kegiatan usaha biasa disebut sebagai Perusahaan dominan. Perusahaan yang dianggap memiliki posisi dominan juga dapat mengendalikan kegiatan pasar dan memiliki pesaing yang tidak mempunyai kekuatan ataupun dampak besar pada kegiatan pasarnya. Perilaku penyalahgunaan oleh pelaku usaha yang memiliki posisi dominan dalam kegiatan pasar yang bersangkutan memiliki kemungkinan untuk melakukan perbuatan anti-persaingan lainnya. Pelaku usaha dapat menggunakan posisi dominan karena memiliki bargaining position yang mempengaruhi persaingan juga dapat dipertimbangkan sebagai penyalahgunaan. ${ }^{6}$ Dengan posisi dominan yang mereka miliki mereka bisa melakukan rencana ataupun strategi yang bersifat privat atau independen dan tidak dapat dipengaruhi oleh pesaing maupun konsumen mereka. Dengan kekuatan mereka pada pangsa pasar tersebut mereka dapat menggendalikan pangsa pasar dengan keinginan mereka.

Posisi dominan sendiri bukanlah suatu hal yang baru, hal ini terjadi tidak hanya ketika ada atau tidaknya pandemi. Posisi dominan sendiri umum terjadi dan bukan berarti posisi dominan merupakan tindakan yang salah melainkan bagaimana mereka melakukan kegiatan pasar mereka sebagai perusahaan yang memiliki posisi yang lebih menguntungkan dibandingkan dengan para pesaingnya. Yang menjadi permasalahan mengenai posisi dominan adalah apakah perusahaan tersebut dalam usaha mencapai posisi tersebut melakukan kecurangan dan setelah mencapai posisi dominan apakah mereka melakukan penyalahgunaan itu untuk mempertahankan keuntungan mereka itu. apabila perusahaan melakukan penyalahgunaan kekuatan mereka ini baru bisa dikatakan telah melanggar pasal 25 ini.

Secara langsung ataupun tidak langsung tindakan dari perusahaan yang memiliki posisi dominan berkaitan dengan beberapa pasal dalam Undang-Undang Nomor 5 Tahun 1999 mengenai Larangan Praktek Monopoli dan Persaingan Usaha Tidak Sehat yaitu:

Pasal 6 tentang diskriminanasi harga

Perusahaan yang memiliki posisi dominan mempunyai kekuatan untuk mempengaruhi dengan mengajukan penetapan kebijakan harga melalui perjanjian.

\section{Pasal 17}

Perusahaan dengan posisi dominan memiliki ciri khas dalam kekuatan untuk melakukan monopoli yang menghambat pesaingnya untuk berkembang.

\section{Pasal 19}

Perusahaan yang memiliki posisi dominan berkemampuan untuk menguasai kegiatan pasar sehingga dapat melakukan diskriminasi terhadap pesaingnya.

\section{Pasal 20}


Perusahaan yang memiliki posisi dominan medapatkan kekuatan untuk melakukan penjualan dengan harga yang rendah untuk menyingkirkan para pesaingnya

Perusahaan atau pelaku usaha posisi dominan yang memiliki kekuatan terbesar dalam pasar bukanlah suatu masalah. Posisi dominan tidak menjadi suatu permasalahan ketika hal tersebut dicapai melalui persaingan yang sehat diraih melalui efisiensi kerja mereka, inovasi atau ide dan strategi usaha yang mengungguli para pesaingnya. Efisiensi serta inovasi yang dicoba oleh industri dominan tersebut hendak diterjemahkan dalam wujud harga yang lebih murah serta mutu benda yang lebih baik. Perkara tersebut akan timbul apabila tidak menghasilkan kondisi pasar seperti yang diharapkan.

Penyalahgunaan posisi dominan umumnya bisa dilihat dari sikap strategis industri atau strategic behavior. Strategic behavior merupakan suatu konsep bagaimana suatu usaha dapat mengurangi tingkatan persaingan yang berasal dari pesaing yang telah ada ataupun pesaing potensial yang baru memulai di pasar yang pada dasarnya diperuntukan untuk tingkatkan profit perusahaan. Sikap ini tidak hanya dipusatkan pada penetapan harga ataupun kuantitas. Namun lebih mengejar kondisi pasar, memperlebar kapasitas, sampai mempersempit ruang gerak pesaing. Perusahaan atau pelaku usaha posisi dominan dalam masa pandemi menggunakan kesempatan tersebut untuk melakukan hal-hal tersebut dengan strategi menimbun produk mereka seperti masker, hand sanitizer dan obat-obatan penjaga imun sehingga para pesaingnya tidak memiliki kekuatan dalam kepemilikian produk memaksa mereka harus mengikuti atau bahkan menurunkan harga mereka untuk dapat mengikuti persaingan di pasar dan menyempitkan pergerakan mereka sebagai pesaing. Ketika para pesaing mereka telah terperangkap dalam strategi itu maka dapat terjadi monopoli yang dilakukan oleh perusahaan yang memiliki posisi dominan. Oleh karena itu persaingan menjadi tidak seimbang dan menimbulkan persaingan usaha tidak sehat. Selain strategic behavior dalam penyalahgunaan posisi dominan juga ada predatory pricing di mana perusahaan menjual produk mereka dengan harga di bawah biaya produksi sehingga para pesaing kecil mereka dapat tersisihkan dan tidak mampu untuk bersaing. Tetapi selama masa pandemi perusahaan tidak melakukan predatory pricing dikarenakan kelangkaan terhadap barang sehingga tidak perlunya melakukan penurunan harga tetapi dengan menguasai produk dagang yang bersangkutan.

KPPU dalam pembuktian dugaan penyalahgunaan posisi dominan, menggunakan pendekatan yang dapat dibagi ke dalam tiga-tahap (3 step process), yaitu:

a. "Pendefinisian pasar bersangkutan;

b. Pembuktian adanya posisi dominan di pasar bersangkutan;

c. Pembuktian apakah pelaku usaha yang memiliki posisi dominan tersebut telah melakukan penyalahgunaan posisi dominan;"7

\section{Price fixing}

Price fixing atau penetapan harga adalah perjanjian yang dilarang untuk dilakukan oleh para pelaku usaha dalam hal menetapkan harga atas kualitas suatu barang dan/atau jasa yang harus dibayarkan oleh pihak konsumen atau pelanggan dalam pasar yang memiliki keterkaitan. Kegiatan ini sangatlah dilarang dalam persaingan usaha karena dapat menghasilkan kenaikan harga yang tidak normal. Bersumber pada Undang-Undang nomor 5 tahun 1999 Menurut pasal 1 ayat 7 "perjanjian didefenisikan bagaikan suatu perbuatan satu atau lebih pelaku usaha untuk mengikatkan diri terhadap satu ataupun lebih pelaku usaha lain dengan nama apapun, baik tertulis ataupun tidak tertulis" Perjanjian penetapan harga/Price fixing tercantum di dalam jenis perjanjian yang dilarang yang diatur dalam Pasal 5 sampai dengan Pasal 8 UU nomor 5 Tahun 1999 yang terdiri dari perjanjian penetapan harga (Price fixing Agreement), diskriminasi harga (Price Discrimination), harga pemangsa ataupun jual rugi (predatory pricing). ${ }^{8}$

Dalam pasal 8 UU Nomor 5 Tahun 1999 menyatakan bahwa "Pelaku usaha dilarang membuat perjanjian dengan pelaku usaha lain yang memuat persyaratan bahwa penerima barang dan atau jasa tidak akan menjual atau memasok kembali barang dan atau jasa yang diterimanya, dengan harga yang lebih rendah daripada harga yang telah diperjanjikan sehingga dapat mengakibatkan terjadinya persaingan usaha tidak sehat." Selain itu, perjanjian yang dilakukan pelaku usaha telah memenuhi unsur daripada ketentuan Pasal 1313 Kitab UndangUndang Hukum Perdata, "yang menentukan bahwa suatu persetujuan adalah suatu perbuatan dengan mana satu orang atau lebih mengikatkan dirinya terhadap satu orang atau lebih". tau secara singkat pelaku usaha tidak diperbolehkan melakukan perjanjian dengan pesaingnya yang berkaitan dengan penerimaan barang atau jasa, menjualnya dengan harga yang lebih rendah dari perjanjian.

Diskriminasi harga merupakan penawaran/pembebanan harga yang berbeda terhadap masing-masing konsumen. Biasanya kegiatan ini dapat terjadi pada pasar persaingan tidak sempurna, yang lebih khusus lagi pasar monopoli di

\footnotetext{
${ }^{7}$ Komisi Pengawas Persaingan Usaha, Pedoman Pasal 25 Tentang Larangan Penyalahgunaan Posisi Dominan Berdasarkan Undang-Undang No. 5 Tahun 1999 Tentang Larangan Praktek Monopoli dan Persaingan Usaha Tidak Sehat

${ }^{8}$ Fahmi, Andi. Hukum Persaingan Usaha:Antara Teks \& Konteks, Indonesia. 2009.
} 
mana perusahaan atau pelaku usaha memiliki kekuatan mutlak atas harga, kuantitas dan kualitas dari produk. Diskriminasi harga ini memang sulit terjadi dikarenakan perlunya unsur yang menguatkan agar hal tersebut terjadi seperti dalam pasar monopoli atau hanya ada satu penjual dalam pasarnya dan minimnya informasi mengenai barang yang diperjualbelikan. Oleh karena itu diskriminasi harga ini sangat jarang terjadi bahkan dalam masa pandemi tidak terlihatnya suatu kegiatan diskriminasi harga.

Harga pemangsa ataupun jual rugi merupakan suatu bentuk penetapan harga dengan cara menurunkan harga dari suatu barang atau jasa di bawah harga normal yang bertujuan untuk menarik pelanggan, menghalangi para pesaing baru dan menyingkirkan para pesaingnya. Predatory pricing ini biasa bertujuan untuk meningkatkan penjual sehingga menarik konsumen dalam jumlah besar untuk melakukan pembelian hanya ke penjual yang melakukan predatory pricing. Ketika ada perusahaan yang melakukan predatory pricing, konsumen merupakan salah satu pihak yang sangat diuntungkan, tetapi jika predatory pricing tersebut berhasil dan menyingkirkan seluruh pesaingnya yang tidak dapat bersaing maka ketika seluruh pesaingnya telah mundur dari pasar, perusahaan atau pelaku usaha yang melakukan predatory pricing akan mendapatkan penguasaan yang mutlak akan pasar yang menciptakan persaingan tidak sempurna dan pihak perusahaan dapat melakukan penetapan harga secara tinggi dikarenakan hanya perusahaan tersebut yang menjadi satu-satunya perusahaan yang masih bertahan dalam pasar. Predatory pricing selama masa pandemi tidak terlihat secara signifikan dikarenakan selama masa pandemi para perusahaan atau pelaku usaha dalam bidang penjualan masker, hand sanitizer dan obat-obatan mengalami kewalahan dikarenakan kondisi yang memaksakan oleh konsumen melakukan pembelian secara besar dan para konsumen tidak memikirkan masalah harga karena barang yang diperjualbelikan merupakan barang yang menyangkut kelangsungan hidup mereka.

Perjanjian penetapan harga diatur dalam Pasal 5 UU No. 5 Tahun 1999, sebagai berikut:

1. "Pelaku usaha dilarang membuat perjanjian dengan pelaku usaha pesaingnya untuk menetapkan harga atas suatu barang dan atau jasa yang harus dibayar oleh konsumen atau pelanggan pada pasar bersangkutan yang sama."

2. "Ketentuan sebagaimana dimaksud pada ayat 1 tidak berlaku untuk:

a. suatu perjanjian yang dibuat dalam suatu usaha patungan; atau

b. suatu perjanjian yang didasarkan undang-undang yang berlaku.",

Price fixing atau penetapan harga ini sendiri dalam UU Nomor 5 Tahun 1999 memiliki keterkaitan dengan beberapa pasal di dalamnya yaitu: ${ }^{9}$

\section{Pasal 8}

Dalam pasal ini pengaturan Price fixing sendiri berlaku secara horizontal maupun vertikal, apabila secara horizontal berkaitan dengan pesaingnya dalam bidang yang sama, apabila vertikal berkaitan dengan perusahaan yang berada di atas maupun di bawahnya entah sebagai produsen maupun distributor.

\section{Pasal 16}

Menurut pasal ini para pelaku usaha dilarang untuk melakukan perjanjian dengan pihak lain di luar negeri yang dapat menyebabkan persaingan usaha tidak sehat. Seperti perjanjian dengan produsen ataupun importir dari luar negeri, yang dapat menghampat kelancaran pasar.

Pelaku usaha dilarang membuat perjanjain dengan pelaku usaha persaingan yang bertujuan untuk membagi wilayah pemasaran atau alokasi pasar terhadap barang dan atau jasa sehingga dapat mengakibatkan terjadinya praktek monopoli dan atau persaingan usaha tidak sehat. ${ }^{10}$

Terdapat beberapa hal juga yang harus dicermati dalam menilai apakah pelaku usaha melakukan Price fixing atau tidak. Apabila tidak adanya perjanjian antara sesama pelaku usaha dalam kesamaan harga jual atau hanya sekedar ketidak sengajaan tanpa adanya bukti perjanjian maka tidak dapat disebut sebagai penetapan harga.

Menurut Pedoman Pasal 5 Undang-Undang Nomor 5 Tahun 1999 oleh KPPU "Secara umum bentuk-bentuk penetapan harga yang termasuk ke dalam aturan pelarangan pasal 5 UU No.5 Tahun 1999 adalah berikut ini (namun tidak terbatas pada):

a. Kesepakatan menaikkan atau menurunkan harga;

b. Kesepakatan memakai suatu formula standart sebagai dasar perhitungan harga;

\footnotetext{
${ }^{9}$ Komisi Pengawas Persaingan Usaha. 2011. Pedoman Pasal 5 Tentang Penetapan Harga Berdasarkan Undang-Undang No. 5 Tahun 1999 Tentang Larangan Praktek Monopoli dan Persaingan Usaha Tidak Sehat.

${ }^{10}$ Febrina, Rezmina, "Dampak Kegiatan Jual Rugi (Predatory Pricing) Yang Dilakukan Pelaku Usaha Dalam Perspektif Persaingan Usaha", Volume. 4 Nomor. 2, Mei 2017, Jurnal Selat.
} 
c. Kesepakatan memelihara suatu perbandingan tetap antara harga yang dipersaingkan dengan suatu produk tertentu;

d. Kesepakatan meniadakan diskon atau membuat keseragaman diskon;

e. Kesepakatan persyaratan pemberian kredit kepada konsumen;

f. Kesepakatan meniadakan produk yang ditawarkan dengan harga murah di pasar sehingga membatasi pasokan dan memelihara harga tinggi.

g. Persetujuan kepatuhan pada harga yang diumumkan;

h. Kesepakatan tidak menjual bila harga yang disetujui tidak dipenuhi;

i. Kesepakatan menggunakan harga yang seragam sebagai langkah awal untuk negosiasi;"

Yang diperlukan dalam pembuktian dugaan penetapan harga adalah bukti bahwa penetapan harga keduabelah pihak para pelaku usaha mematuhi kesepakatan itu. ${ }^{11}$ Bukti-bukti yang di haruskan berupa Bukti Langsung (Hard evidence) dan Bukti tidak langsung (Circumstantial evidence) "Di dalam Lampiran Peraturan Komisi Pengawas Persaingan Usaha Nomor 4 Tahun 2011 Tentang Pedoman Pasal 5 Undang-Undang Anti Monopoli yang bertujuan dari pembuktian dengan bukti yang tidak langsung dengan menggunakan bukti ekonomi adalah usaha untuk mengesampingkan suatu terjadinay penetapan harga yang independent." 12

Membahas mengenai perjanjian penetapan harga para pelaku usaha berkoordinasi untuk menaikkan untuk mendapatkan keuntungan yang sangat tinggi, ketika seluruh penjual maupun produsen melakukan kenaikan harga barang ataupun jasa yang mereka berikan bersifat sangat penting dan esensial seperti yang terjadi dalam masa pandemi di mana masker, hand sanitizer dan obat-obatan menimbulkan harga dari barang tersebut melambung tinggi menciptakan pasar yang tidak stabil. Apabila para pelaku usaha yang sudah merencanakan strategi tersebut maka mereka akan mencoba untuk menguasai kuantitas barang tersebut sehingga mereka mendapatkan keuntungan sebagai pelaku usaha dalam posisi dominan yang dapat memainkan harga sesuai dengan keinginan. Memang kegiatan dari Price fixing yang terjadi pada masa pandemi ini tidak dapat terlepas dari posisi dominan, perjanjian antar pelaku usaha yang saling berkaitan dan juga memanfaatkan kondisi yang terjadi di mana para masyarakat yang panik akan keadaan melakukan panic buying (situasi dimana masyarakat melakukan pembelian dalam jumlah besar untuk mengantisipasi bencana), Direktur Eksekutif Institute for Development of Economics and Finance (INDEF) Enny Sri Hartanti "mengatakan, perilaku ini dipicu oleh factor psikologis terjadi akibat informasi tidak sempurna atau menyeluruh yang diterima oleh masyarakat. Pada akhirnya, masyarakat menjadi khawatir sehingga timbullah respons berupa belanja secara pasif dalam upaya penyelamatan diri". ${ }^{13}$ Apabila secara keseluruhan panic buying dan kelangkaan barang telah terjadi maka para pelaku usaha memiliki kesempatan untuk menaikkan harga barang jauh dari biaya produksi maupun biaya beli sebagai distributor untuk mencapai dan mempertahankan keuntungan mereka. Apabila para pelaku usaha menyetujui dan melakukan tindakan tersebut maka mereka mendapatkan keuntungan yang jauh lebih tinggi dibanding pesaing mereka yang tidak melakukan Price fixing. Dampak panic buying sendiri sangat besar dalam Price fixing dalam masa pandemi karena ketika banyak pelaku usaha yang telah kehabisan barang dagang maka barang tersebut menjadi langka dan sulit untuk didapatkan, dikarenakan kelangkaan barang tersebut maka harga akan naik (ketika permintaan memuncak tetapi kuantitas barang tidak memadai permintaan maka akan terjadi kenaikan harga yang dikarenakan kelangkaan barang tersebut) ketika kelangkaan tersebut muncul para pelaku usaha yang masih memiliki barang dagang tersebut akan menaikkan harga barang, karena barang yang diperjualbelikan adalah masker, hand sanitizer dan obat-obatan merupakan barang penting dan menyangkut kelangsungan hidup manusia sehingga para konsumen tidak ragu untuk melakukan pembelian dan para pelaku usaha juga memanfaatkan kondisi untuk meraup untung yang maksimal. Yang menjadi permasalahan dengan Price fixing yang terjadi ketika pandemi adalah munculnya para panic buyer yang berubah menjadi penjual dikarenakan tergiur dengan keuntungan yang dapat diraih dari menjual barang tersebut dan menjualnya kembali dengan menaikkan lagi harga yang telah meninggi sehingga menimbulkan suatu siklus perdagangan yang tidak sehat. Para panic buyer melakukan penjualan kembali karena kepemilikan barang mereka terhadap suatu barang yang langka sangatlah banyak dan melirik keuntungan yang akan mereka dapatkan ketika menjual barang-barang tersebut kembali. Dikarenakan hal tersebut pasar untuk masker, hand sanitizer dan obat-obatan mencapai harga yang tidak normal kenaikan yang terjadi bisa mencapai 10x lipat dari harga normal.

Untuk melancarkan kegiatan para pelaku usaha yang curang mereka dengan melakukan penimbunan sehingga posisi dominan ini dengan mudah dicapai, dikarenakan semakin besar dan dominan kepemilikian suatu produk barang maka mereka juga dapat mengatur kegiatan yang terjadi di pasar dan mendapatkan kekuatan untuk mengatur ataupun

${ }^{11}$ Rachmadi Usman. Hukum Persaingan Usaha Di Indonesia. hal 231. 2013.

${ }^{12}$ Dewi, A.A Ayu Wulan Ratna. Sarajana, I Made. Mudana, I Nyoman. Pelanggaran Penetapan Harga Oleh Pelaku Usaha Dengan Pelaku Usaha Pesaing (Studi Kasus Putusan Kppu Nomor 04/Kppu-I/2016), Kertha Semaya. 2018

${ }^{13}$ Indriani, Anggy Lia, “dampak covid-19 terhadap penimbunan barang (panic buying)”, UIN Antasari, 2020 
mengkontrol pesaing mereka. secara hukum penimbunan ini diatur dalam Pasal 29 Undang-Undang Nomor 7 Tahun 2014 Mengenai Perdagangan, yang dimana menurut pasal tersebut "dilarang menyimpan kebutuhan pokok/barang penting dengan jumlah dan waktu tertentu pada saat terjadi kelangkaan barang, gejolak harga dan/atau hambatan pada lalu lintas perdagangan barang". ${ }^{14}$ Menurut Peraturan Presiden Nomor 71 Tahun 2015 Tentang Penetapan dan Penyimpanan Barang Kebutuhan Pokok dan Barang Penting tidak menyebutkan bahwa barang yang langka ataupun kebutuhan pokok yang muncul pada saat pandemi, seperti masker, hand sanitizer dan obat-obat penjaga imun. Tetapi harus kita pahami lagi bahwa kebutuhan pokok merupakan barang yang menyangkut kehidupan dan sangat dibutuhkan sebagai faktor pendukung kesehatan orang banyak. Karena itu masker, hand sanitizer dan obat-obatan penjaga imun dapat dijadikan sebagai kebutuhan pokok selama masa pandemi karena menyangkut kelangsungan hidup orang banyak. Harus kita pahami juga bahwa dalam pasal 2 ayat 7 Peraturan Presiden Nomor 71 Tahun 2015 dijelaskan bahwa jenis barang kebutuhan pokok/barang penting dapat diubah berdasarkan usulan menteri perdagangan setelah berkoordinasi dengan menteri/kepala lembaga pemerintah nonkementrian terkait. Menteri Perdagangan bapak Agus Suparmanto mengimbau para pelaku bisnis untuk tidak melakukan penimbunan barang kebutuhan pokok dan produk kesehatan seperti masker. Karena, menurut dirinya, barang-barang tersebut diperlukan oleh masyarakat di tengah keresahan yang diakibatkan merebaknya wabah virus corona Covid-19. "Imbauan ini akan dilanjutkan dengan peringatan dan sanksi yang tegas kepada para pelaku penimbunan barang yang tidak bertanggung jawab," kata Agus dalam keterangan tertulis Kamis, 5 Maret 2020. ${ }^{15}$ Memang dalam kondisi saat ini terjadinya kekacauan dan kegagalan dalam pasar oleh karena itu pentingnya peranan pemerintah sebagai pengatur kegiatan ekonomi dan perdagangan yang mutlak untuk menjerat pihak-pihak yang menyebabkan terjadinya kelangkaan barang dan Price fixing. Selain menjerat pihak-pihak tersebut, perlunya juga untuk memberikan peraturan secara tertulis yang memiliki kekuatan hukum tetap sehingga dapat memberikan peringatan bahwa kegiatan usaha mereka dapat menganggu kelancaran pasar dan memberikan sanksi yang setimpal sehingga menimbulkan efek jera kepada para pelaku.

Posisi dominan, Price fixing dan penimbunan merupakan tiga perilaku kecurangan pelaku usaha yang berkaitan satu sama lain selama masa pandemi. Apabila pelaku usaha melakukan penimbunan dan menguasai barang sehingga terjadinya kelangkaan di pasar menghasilkan perusahaan berada dalam posisi dominan, ketika perusahaan atau pelaku usaha telah mencapai posisi dominan ia dapat melakukan Price fixing untuk mendapatkan keuntungan yang maksimal. Selain itu perusahaan dalam posisi dominan melakukan penimbunan untuk melemahkan pesaingnya yang memiliki keterkaitan sehingga mereka mendapatkan penguasaan pasar secara mutlak.

\section{Bagaimana akibat hukum terhadap pengusaha yang melakukan kecurangan tersebut selama masa pandemi Akibat hukum jika terjadi Penyalahgunaan Posisi dominan dalam keadaan Pandemi}

Penyalahgunaan Posisi Dominan memiliki arti suatu perbuatan yang dilakukan pelaku usaha dalam posisi dominan yang melanggar dan menyalahgunakan hal yang dilarang dalam Undang-Undang Nomor 5 Tahun 1999 Tentang Larangan Praktek Monopoli dan Persaingan Usaha Tidak Sehat. Apabila perusahaan atau pelaku usaha terbukti melakukan penyalahgunaan posisi dominan dapat dikenakan beberapa sanksi yaitu:

\section{Pasal 47 Tindakan Administratif Ayat 2}

\section{Hurufb}

"Perintah kepada pelaku usaha untuk menghentikan kegiatan yang terbukti menimbulkan praktek monopoli dan atau menyebabkan persaingan usaha tidak sehat dan atau merugikan masyarakat; dan atau”. Apabila penyalahgunaan posisi dominan tersebut terbukit maka pelaku usaha tersebut wajib menghentikan kegiatan penyalahgunaan tersebut karena menimbulkan persaingan usha tidak sehat dan merugikan masyarakat.

\section{Hurufe}

"Penetapan pembayaran ganti rugi dan atau". Pelaku penyalahgunaan posisi dominan diharuskan melakukan ganti rugi kepada pihak yang telah dirugikan oleh kegiatan usahanya

\section{Huruff}

"Pengenaaan denda serendah-rendahnya $R p$ 1.000.000.000.00 (satu milyar rupiah) dan setinggi-tingginya $R p$ 25.000.000.000.00 (duapuluh milyar rupiah)". Pelaku penyalahgunaan posisi dominan dapat dikenakan denda sebesar satu miliyar rupiah dan setinggitingginya dua puluh milyar rupiah apabila terbukti melakukan tindakan tersebut.

\footnotetext{
${ }^{14}$ Pasal 29 Undang-Undang Nomor 7 Tahun 2014 tentang Perdagangan

15 https://bisnis.tempo.co/read/1316131/mendag-ancam-cabut-izin-pelaku-usaha-penimbun-masker/full\&view=ok $($ diakses pada tanggal 19 Januari 2021 pukul 15.00 WIB)
} 
Abraham Radja dan Imam Haryanto, Akibat Hukum Pengusaha Melakukan Perbuatan Curang pada Masa Pandemi Dikaitkan dengan Perundang-Undangan Yang Berlaku

Pasal 48 Pidana Pokok ayat 1

"Pelanggaran terhadap ketentuan Pasal 4, Pasal 9 sampai dengan Pasal 14, Pasal 16 sampai dengan Pasal 19, Pasal 25, Pasal 27, dan Pasal 28 diancam pidana denda serendah-rendahnya Rp 25.000.000.000,00 (dua puluh lima miliar rupiah) dan setinggitingginya Rp 100.000.000.000,00 (seratus miliar rupiah), atau pidana kurungan pengganti denda selama-lamanya 6 (enam) bulan."

Pihak yang terbukti melanggar Pasal 25 mengenai posisi dominan dapat dikenakan pidana denda serendahrendahnya dua puluh lima miliar rupiah dan setinggi-tingginya seratus miliar rupiah atau pidana kurungan pengganti denda selama-lamanya enak bulan.

Pasal 49 Pidana Tambahan huruf a \& $c$

"Dengan menunjuk ketentuan Pasal 10 Kitab Undang-undang Hukum Pidana, terhadap pidana sebagaimana diatur dalam Pasal 48 dapat dijatuhkan pidana tambahan berupa:

a. Pencabutan izin usaha; atau

c. Penghentian kegiatan atau tindakan tertentu yang menyebabkan timbulnya kerugian pada pihak lain.”

Merujuk pada pasal 10 KUHP di mana terdapatnya pidana tambahan, maka dalam persaingan usaha juga terdapat pidana tambahan seperti pencabutan izin ataupun penghentian kegiatan atau tindakan yang dilakukan oleh perusahaan atau pelaku usaha.

Price fixing

Peraturan mengenai Price fixing sendiri terdapat pada Undang-Undang Nomor 5 Tahun 1999 yaitu:

Pasal 47 Sanksi administratif huruf $a, c, f \& g$

a. "penetapan pembatalan perjanjian sebagaimana dimaksud dalam Pasal 4 sampai dengan Pasal 13, Pasal 15, dan Pasal 16; dan atau"

c. "perintah kepada pelaku usaha untuk menghentikan kegiatan yang terbukti menimbulkan praktek monopoli dan atau menyebabkan persaingan usaha tidak sehat dan atau merugikan masyarakat; dan atau”

Dalam huruf a dijelaskan bahwa apabila terjadinya Price fixing agreement para pihak yang bersangkutan wajib membatalkan kewajiban mereka. Dikarenakan Price fixing menimbulkan persaingan usaha tidak sehat maka dapat dikenakan sanksi administratif seperti pada pasal 47 ini, dan dapat dikenakan denda sebesar satu miliar rupiah sampai dua puluh lima miliar rupiah.

Pasal 48 Pidana Pokok ayat 2

“(2) Pelanggaran terhadap ketentuan Pasal 5 sampai dengan Pasal 8, Pasal 15, Pasal 20 sampai dengan Pasal

24, dan Pasal 26 Undang-undang ini diancam pidana denda serendah-rendahnya Rp 5.000.000.000,00 (lima miliar rupiah) dan setinggi-tingginya Rp 25.000.000.000,00 (dua puluh lima miliar rupiah), atau pidana kurungan pengganti denda selama-lamanya 5 (lima) bulan."

Menururt pasal 48 pihak yang terbukti melakukan Price fixing dalam bentuk apapun diancam pidana denda sebesar lima miliar rupiah dan setinggi-tingginya dua puluh lima miliar rupiah/pidana kurungan pengganti denda selama lima bulan.

Pasal 49 Pidana Tambahan

"Dengan menunjuk ketentuan Pasal 10 Kitab Undang-undang Hukum Pidana, terhadap pidana sebagaimana diatur dalam Pasal 48 dapat dijatuhkan pidana tambahan berupa:

a. pencabutan izin usaha; atau

b. larangan kepada pelaku usaha yang telah terbukti melakukan pelanggaran terhadap undang-undang ini untuk menduduki jabatan direksi atau komisaris sekurang-kurangnya 2 (dua) tahun dan selama-lamanya 5 (lima) tahun; atau

c. Penghentian kegiatan atau tindakan tertentu yang menyebabkan timbulnya kerugian pada pihak lain.”

Menurut R. Soesilo dalam buku Kitab Undang-Undang Hukum Pidana (KUHP) Serta Komentar-Komentarnya Lengkap Pasal Demi Pasal (hal. 36) menjelaskan bahwa "selain hukuman pokok, maka dalam beberapa hal yang ditentukan dalam undang-undang dijatuhkan pula (ditambah) dengan salah satu dari hukuman tambahan." Oleh karena 
itu pihak yang terbukti melakukan Price fixing dapat dikenakan pidana tambahan. Contoh pemberian pidana tambahan kepada para pelaku kecurangan yaitu dapat berupa pencabutan hak melakukan usaha ataupun penyitaan terhadap barang dagangannya.

\section{Penimbunan}

Pihak yang melakukan penimbunan barang terhadap barang pokok dan barang penting maka dapat dijerat dengan pasal 107 Undang-Undang Nomor 7 Tahun 2014 Tentang Perdagangan yang berisi:

"Pelaku Usaha yang menyimpan Barang kebutuhan pokok dan/atau Barang penting dalam jumlah dan waktu tertentu pada saat terjadi kelangkaan Barang, gejolak harga, dan/atau hambatan lalu lintas Perdagangan Barang sebagaimana dimaksud dalam Pasal 29 ayat 1 dipidana dengan pidana penjara paling lama 5 (lima) tahun dan/atau pidana denda paling banyak Rp50.000.000.000,00 (lima puluh miliar rupiah)."

Apabila pelaku tersebut juga melakukan perjanjian penimbunan barang atau perjanjian penguasaan terhadap suatu produksi yang terdapat pada pasal 4 ayat 1 Undang-Undang Nomor 5 Tahun 1999 yang berisi:

“(1) Pelaku usaha dilarang membuat perjanjian dengan pelaku usaha lain untuk secara bersama-sama melakukan penguasaan produksi dan atau pemasaran barang dan atau jasa yang dapat mengakibatkan terjadinya praktek monopoli dan atau persaingan usaha tidak sehat."

Dapat dikenakan pasal 47 Tindakan Administratif. Sanksi administratif tersebut adalah

a. Pembatalan perjanjian para pihak yang menjadi dasar perbuatan mereka

b. Menghentikan kegiatan mereka yang dapat menganggu persaingan usaha dan/atau merugikan masyarakat

c. Penetapan ganti rugi

\section{Pasal 48 Pidana Pokok ayat 1}

Diancam denda paling rendah dua puluh lima miliar rupiah dan paling tinggi sebesar seratus miliar rupiah atau pidana kurungan pengganti denda selama-lamanya enam bulan.

\section{Pasal 49 Pidana Tambahan}

a. Pencabutan izin usaha

b. Pelaku usaha yang telah terbukti dilarang untuk menduduki jabatan direksi/komisaris sekurang-kurangnya 2 tahun dan selama-lamanya 5 tahun; atau

c. Menghentikan kegiatan pelaku usaha yang menimbulkan kerugian pada pihak lain.

\section{SIMPULAN}

Perbuatan curang berupa posisi dominan, penetapan harga, dan penimbunan adalah suatu bentuk perbuatan curang yang saling berkaitan yang dilakukan oleh para pelaku usaha dalam masa pandemi yang terjadi sekarang ini. Para pelaku usaha melakukan penimbunan barang-barang pokok pada masa pandemi seperti masker, hand sanitizer, dan obat-obatan. Penimbunan barang ini mengakibatkan terjadinya kelangkaan pada pasar, dengan demikian para pelaku usaha dapat mencapai posisi dominan. Pelaku usaha yang sudah berada dalam posisi dominan dengan mudahnya dapat memainkan harga sesuai keinginan dengan melakukan perjanjian penetapan harga antara para pelaku usaha, hal ini menyebabkan harga dari barang-barang yang dibutuhkan pada saat pandemi melambung tinggi sehingga pasar menjadi tidak stabil. Perbuatan curang yang dilakukan pelaku usaha pada masa pandemi ini juga terjadi karena adanya suatu keadaan dalam masyarakat yang dinamakan panic buying yang timbul sebagai upaya untuk menyelamatkan diri khususnya dalam situasi pandemi. Panic buying ini menyebabkan kelangkaan pada suatu barang sehingga para pelaku usaha memanfaatkan keadaan tersebut untuk menaikkan harga barang dengan tinggi.

\section{DAFTAR PUSATAKA}

\section{Buku}

Ditha Wiradiputra, S.H.. 2004. (Staf Pengajar FHUI, Direktur Eksekutif Lembaga Kajian Persaingan dan Kebijakan Usaha FHUI), Modul untuk Retooling Program under Employee Graduates at Priority Disiciplines under TPSDP (Technology and Profesional Skills Development Sector Project) DIKTI. Tanggal 14 September 2004, Jakarta. Pengantar Hukum Persaingan Usaha Indonesia

Fahmi, Andi. Hukum Persaingan Usaha:Antara Teks \& Konteks, Indonesia. 2009.

Rachmadi Usman. Hukum Persaingan Usaha Di Indonesia. 2013. 
Abraham Radja dan Imam Haryanto, Akibat Hukum Pengusaha Melakukan Perbuatan Curang pada Masa Pandemi Dikaitkan dengan Perundang-Undangan Yang Berlaku

\section{Undang-Undang}

Kitab Undang-Undang Hukum Perdata

Peraturan Presiden Nomor 71 Tahun 2015 Tentang Penetapan dan Penyimpanan Barang Kebutuhan Pokok dan Barang Penting

Undang-Undang No. 5 Tahun 1999 Tentang Larangan Praktek Monopoli dan Persaingan Usaha Tidak Sehat

Undang-Undang No. 8 Tahun 1999 Tentang Perlindungan Konsumen

Undang-Undang Nomor 7 Tahun 2014 Tentang Perdagangan

\section{Jurnal}

Komisi Pengawas Persaingan Usaha. 2010. Pedoman Pasal 25 Tentang Larangan Penyalahgunaan Posisi Dominan Berdasarkan Undang-Undang No. 5 Tahun 1999 Tentang Larangan Praktek Monopoli dan Persaingan Usaha Tidak Sehat

Komisi Pengawas Persaingan Usaha. 2011. Pedoman Pasal 5 Tentang Penetapan Harga Berdasarkan Undang-Undang No. 5 Tahun 1999 Tentang Larangan Praktek Monopoli dan Persaingan Usaha Tidak Sehat.

Organisation for Economic Co-operation and Development OECD. Abuse of Dominance and Monoplisation. 1996.

Dewi, A.A Ayu Wulan Ratna. Sarajana, I Made. Mudana, I Nyoman. 2018. "Pelanggaran Penetapan Harga Oleh Pelaku Usaha Dengan Pelaku Usaha Pesaing (Studi Kasus Putusan Kppu Nomor 04/Kppu-I/2016)”. Vol. 01, No. 12, November 2013. Kertha Semaya. Universitas Udayana.

Dewi, Ni Putu Tryana Tresna. Westra, I Ketut. "Kajian Yuridis Terhadap Perjanjian Penetapan Harga Dalam Putusan Kppu Perkara Nomor 14/Kppu-I/2014” Vol 7 No 9 2019. Kertha Semaya. Universitas Udayana.

Febrina, Rezmina. "Dampak Kegiatan Jual Rugi (Predatory Pricing) Yang Dilakukan Pelaku Usaha Dalam Perspektif Persaingan Usaha". Volume. 4 Nomor. 2. Mei 2017. Jurnal Selat.

Indriani, Anggy Lia. "Dampak Covid-19 Terhadap Penimbunan Barang (Panic Buying)". 2020. Kuliah, Mata, and Etika Bisnis Islam. UIN Antasari

\section{Website}

https://humas.polri.go.id/download/polda-sulsel-bongkar-penyalahgunaan-perdagangan-22-ribu-masker-di-makassar/ (diakses pada tanggal 5 April 2021 pukul 20.00)

https://bisnis.tempo.co/read/1316131/mendag-ancam-cabut-izin-pelaku-usaha-penimbun-masker/full\&view=ok (diakses pada tanggal 19 Januari 2021 pukul 15.00 WIB) 